\title{
Workforce issues and their impact on projects: study on the Indian IT and ITeS industry
}

\author{
Dr Nasina Jigeesh, IBS Hyderabad, IFHE University, India
}

\begin{abstract}
Today's information technology (IT) industry is facing challenges from different corners because of globalisation, technological changes, market and economic fluctuations and dynamic changes in customer requirements. A new stream of jobs has been emerging from time to time in the IT and IT-enabled services (ITeS) industry. People management is gaining more concern compared with technology management. Recruiting the right people, motivating them to improve their productivity and retaining productive people are becoming additional challenges to the success of IT projects, and for enabling the IT industry to achieve steady growth and continue ongoing projects without any interruptions or constraints. This study focuses on the dynamics of the workforce in IT projects, and analyses the important issues of managing the workforce and its impact on time, cost and quality of the projects. From the analysis of data collected through surveys of some big IT and ITeS companies in India, it was found that the availability of human resources (HR) was the most significant issue, while the issue of employee-oriented programs was the least significant.
\end{abstract}

Keywords: Information technology, information technology-enabled services, IT projects, human resource management

\section{Introduction}

Due to the competitive environment prevailing globally, every industry, for its survival, has been aggressively designing and implementing new business processes to produce better and innovative products or services. Rowden (2002) recommended several factors for organisational success which included the careful selection of employees, matching the employee's skills or skills development potential with the needs of the company, investment in training and employee-development activities, retention of employees by providing them with compensation and benefit packages, etc. Creation of highperformance work environments within the organisations to fulfil human, social and psychological needs leads to increased productivity, product quality innovation and flexibility (Mirivis 1993; Schutz 1994). Rowden (2002) also added that, by allowing workers to influence their work activities, organisations can take competitive advantage of the human element. According to Pfeffer (1994), certain employment practices, including internal career ladders, workers discretion and extensive training, generally contribute to high levels of organisational performance. The information technology (IT) and IT-enabled services (ITeS) industry would also exhibit all these features.

In industries other than IT, but relying on IT applications, there would be a reduction of workforce in organisations (Jonscher 1994); Brynjolfsson et al 1994), hampering the motivation levels of employees. Continuing pressures associated with globalisation, technological change and market deregulation suggest a continuing need for firms to use 
some form of downsizing and restructuring (Lawler et al 2000). But in the IT industry, the projects to bring up different IT applications/products/services have been growing day by day and this trend is creating a demand for a larger IT workforce. The reasons for and repercussions of the market forces reported by Lawler et al (2000) might be experienced in IT firms also. Maintaining innovation at all levels in products and services has been adding valuable support to competitive advantage of IT firms, which need to encourage creativity and innovation as part of the organisational mission. According to Galunic and Rodan (1998), the HR skills and motivation levels make it possible for creative suggestions, different proposals and research activities to foster innovation. According to PMBoK, the project HR management processes include HR planning and acquisition, development and management of the project team. HR planning deals with making different people accountable, authorised and responsible for different portions of the project. In the event of project team members not possessing the required competencies to accomplish the assigned project tasks, PMBoK recommends initiating proactive responses such as training, hiring, and schedule or scope changes. While acquiring human resources, their availability, ability, experience, interests and cost play an important role. The project team members should be properly trained to develop their general management skills, formal and informal communications, team-building attitude, etc. The skills and competencies would be improved to perform assigned activities more effectively with good team spirit.

\section{IT and ITeS projects}

The characteristics of IT projects are quite different from other projects. For example, the progress of IT projects is not visible immediately and per dollar or euro spent; software products contain more complexity than other engineered artifacts (Brooks 1987). Just like the invisible nature of status/progress of IT projects, the matching of skills of various project personnel with the project requirements will also become unclear in many cases. Therefore, the process of selection and recruitment of the right project staff in the IT industry is becoming increasingly complex, and the successful outcome of these processes is becoming vital for job performance, organisational success and competitive advantage. Jobs change accordingly as organisations respond to economic and technological pressures in the market and, similarly, skills vary accordingly as the jobs respond to the targets and demands of the market. Jobs and skills along with experience link up with the salary structures, which vary continuously based on different aspects like organisational capabilities, market demand, personal virtue and demands. When all these project and personal parameters are in place, there would be a right balance achieved between the employee's motivation levels and the organisational motivation exercises. Advanced economies has shown a trend of up-skilling and a remarkable variation in the skilled/unskilled composition of labour in the past few years (Machin and Van Reenen 1998; Spitz-Oener 2006). Knowledge workers as human capital can deal with what the target market accepts or expects as value, and are able to defend their companies against the aggressive movements of their competitors (Carneiro 2007). High-performance work practices assist people in the decision-making and problem-solving processes of their work activities (Rowden 2002) and thereby upgrading their motivation levels. 
Poor strategic management and related human factors have been cited as a major cause of failures, which traditional techniques cannot incorporate explicitly (Rodrigues \& Williams 1997). According to Tsai et al (2003), resource selection for choosing the best project team at the planning stage of a software development project is an important issue for reducing project cost, duration and risk. Several research studies (Boehm 1981; Brooks 1993, Krishnan 1998, Martz \& Landof 2000) identified the importance of the team factor in software projects. Krishnan (1998) reported that the major categories of potential improvements in cost and quality of software are focused around technology, software development, process and product factors. Team and group work skills are necessary and increasingly important (Martz \& Landof 2000), but human nature fights against collaboration as shared creation (Corbitt \& Martz 2003).

This study focused on examining the importance and influence of various HR issues on IT project success from the developer's point of view, in terms of the traditional timecost-quality "iron triangle” or "golden triangle" constraints (De Wit 1988; Hazebroucq \& Badot 1996; Atkinson 1999; Cooke-Davis 2002; Westerveld 2003).

\section{Methodology}

Various case studies or success stories of five top Indian IT firms were studied and analysed to derive different challenging issues related to HR and project management. The views of IT professionals and recommendations of PMBoK were taken into account to analyse the issues. In this process, a list of six issues was prepared, excluding the issue of 'commitment'. This is because of the assumption that all the project team members have been working on the projects with commitment. These issues were then compared with the three major project management parameters of time, cost and quality.

The six HR-related issues that were dealt with in this study include:

1. New resources operating new technology,

2. Availability of resources,

3. Skills of team members,

4. Retaining talented people,

5. Motivation, communication and coordination, and

6. Employee-oriented programs.

These issues were then framed in the form of questions and a questionnaire was developed to gather quantitative data on the importance of each HR-related issue and its impact on the time, cost and quality of the project. The questionnaire consisted of four important questions relating to: (a) importance of the issue; (b) impact on quality; (b) impact on cost, and (c) impact on time span of the projects. The questionnaire was sent via email to about 100 IT professionals working in the selected IT companies situated in Bangalore (Karnataka), Chennai (Tamilnadu) and Hyderabad (Andhra Pradesh), which are the three southern Indian software clusters in terms of revenue generation. The feedback from various IT professionals, especially at the level of senior project team leaders and managers was gathered. A Likert scale of 1 to 10 was used to collect the feedback, '1' denoting "not at all important” or "not significant” and '10' representing "very important” or "very significant” and the remaining scores denoting relative 
importance or significance. Of a total of 100 questionnaires forwarded, 33 complete and reliable responses were received. This represents one-third or 33\% response rate, which was treated as reasonable.

All six HR-related issues were analysed together based on the collected feedback on the importance and impact of the HR issues on time, cost and quality of projects. For this purpose, testing of following null hypotheses was done:

1) All six HR-related issues are important in the context of IT projects;

2) All six HR-related issues show equal impact on the quality of IT projects;

3) All six HR-related issues show equal impact on the cost of IT projects; and

4) All six HR-related issues show equal impact on the time of IT projects;

One-way ANOVA (analysis of variance) was used with SPSS 16.0 software. Levene's test was used to test the homogeneity of variances. Post-hoc (Tukey HSD) tests with multiple comparisons among the issues were also performed to assess which issues differed from each other. After testing the above hypotheses, the data was further analysed to assess the importance and type of impact of HR issues on time, cost and quality of IT projects, to make the research work beneficial for any IT project management process.

\section{Hypotheses testing}

The study took up different hypotheses to analyse the variance in the importance and impact of the six HR-related issues on IT projects.

\section{Hypothesis $H_{01}$ : All six $H R$ issues are equally important.}

From the statistical analysis of the feedback data, it was found that the significance is 0.084 in the test of homogeneity of variance, which is greater than 0.05 . Hence it passed Levene's test and all six HR issues have homogeneity of variances. In the case of ANOVA, the significance level, $P=0.000$, is below 0.05 and therefore there is a statistically significant difference regarding mean importance between the different HR issues. Hence the null hypothesis can be rejected. The results showed that 'new resources operating new technology' has no significant difference from the remaining HR issues, except 'employee-oriented programs'. 'Employee-oriented programs' is significantly differenct from two other issues, namely, 'availability of resources' and 'retaining talented people'. 'Availability of resources' also differed in importance from 'skills of team members', 'motivation, communication and coordination', and 'retaining talented people'. Hence, there is significant difference in importance for all the HR issues concerned in IT projects.

In view of the above results, the null hypothesis can be rejected and can be reinterpreted as: Hypothesis $\mathrm{H}_{1}$ : All six $\mathrm{HR}$ issues have significant difference in their importance for IT projects. 


\section{Hypothesis, $\mathrm{H}_{02}$ : All six $\mathrm{HR}$ issues have equal impact on quality in IT projects.}

From the statistical analysis of the feedback data, it was found that the significance is 0.671 in the test of homogeneity of variance, which is greater than 0.05 . Hence the Levene's test is satisfied and all six HR issues have homogeneity of variances. In the case of ANOVA, the significance level, $P=0.082$, which is above 0.05 , and therefore, there is no statistically significant difference between the HR issues in the case of mean impact on quality of projects. Hence the null hypothesis cannot be rejected. But two issues, namely, 'availability of resources' and 'employee-oriented programs' showed some difference compared with the others.

In view of the above result, the null hypothesis cannot be rejected and can be interpreted as: Hypothesis, $\mathbf{H}_{2}$ : All six $\mathbf{H R}$ issues have no significant difference in their impact on quality in IT projects.

\section{Hypothesis $\mathrm{H}_{03}$ : All six HR issues have equal impact on cost in IT projects.}

From the statistical analysis of the feedback data, it was found that the significance is 0.882 in the test of homogeneity of variance, which is greater than 0.05 . Hence it satisfied the Levene's test and all six HR issues have homogeneity of variances. In the case of ANOVA, the significance level, $P=0.000$, which is below 0.05 , and therefore, there is statistically significant difference between the HR issues regarding mean impact on cost of the projects. Hence the null hypothesis can be rejected. The issue of 'availability of resources' has significant difference compared with three other issues, namely, 'retaining talent people', 'motivation, communication and coordination' and 'employee-oriented programs'. Similarly, the issues 'skills of team members' and 'employee-oriented programs' have difference.

In view of the above results, the null hypothesis can be rejected and reinterpreted as:

\section{Hypothesis $\mathrm{H}_{3}$ : All six $\mathrm{HR}$ issues have significant difference in their impact on cost in IT projects.}

\section{Hypothesis, $\mathrm{H}_{04}$ : All six $\mathrm{HR}$ issues have equal impact on time in IT projects.} From the statistical analysis of the feedback data, it was found that the significance is 0.259 in the test of homogeneity of variance, which is greater than 0.05 . Hence the Levene's test is satisfied and all the six HR issues have homogeneity of variances. In the case of ANOVA, the significance level, $P=0.313$, which is greater than 0.05 , and therefore, there is no statistically significant difference between the different HR issues in the case of mean impact on time of IT projects. Hence the null hypothesis cannot be rejected.

In view of the above results, the null hypothesis cannot be rejected and is interpreted as: Hypothesis, $\mathrm{H}_{4}$ : All six $\mathrm{HR}$ issues have no significant difference on their impact time in IT projects.

The above results are represented in Table 1. 
Table 1. Significance values for test of homogeneity of variances and ANOVA of HR issues in IT projects

\begin{tabular}{|c|c|c|c|}
\hline Hypothesis & $\begin{array}{l}\text { Levene's test of } \\
\text { homogeneity - } \\
\text { Significance } \\
\text { value }\end{array}$ & $\begin{array}{l}\text { ANOVA } \\
\text { Significance } \\
\text { value }\end{array}$ & Results \\
\hline $\begin{array}{l}\mathbf{H}_{\mathbf{0 1}} \text { : All six } \\
\text { HR issues are } \\
\text { equally } \\
\text { important. }\end{array}$ & 0.084 & 0.000 & $\begin{array}{l}\text { 1. There is homogeneity of } \\
\text { variances. } \\
\text { 2. There is statistically significant } \\
\text { difference in the mean importance } \\
\text { between the issues. }\end{array}$ \\
\hline $\begin{array}{l}\mathbf{H}_{02} \text { : All six } \\
\text { HR issues have } \\
\text { equal impact } \\
\text { on quality in IT } \\
\text { project. }\end{array}$ & 0.671 & 0.082 & $\begin{array}{l}\text { 1. There is homogeneity of } \\
\text { variances. } \\
\text { 2. There is no statistically } \\
\text { significant difference in the mean } \\
\text { importance between the issues. }\end{array}$ \\
\hline $\begin{array}{l}\mathbf{H}_{\mathbf{0 3}}: \text { All six } \\
\text { HR issues have } \\
\text { equal impact } \\
\text { on cost in IT } \\
\text { projects. }\end{array}$ & 0.882 & 0.000 & $\begin{array}{l}\text { 1. There is homogeneity of } \\
\text { variances. } \\
\text { 2. There is statistically significant } \\
\text { difference in the mean importance } \\
\text { between the issues. }\end{array}$ \\
\hline $\begin{array}{l}\text { H}_{04} \text { : All six } \\
\text { HR issues have } \\
\text { equal impact } \\
\text { on time in IT } \\
\text { projects. }\end{array}$ & 0.259 & 0.313 & $\begin{array}{l}\text { 1. There is homogeneity of } \\
\text { variances. } \\
\text { 2. There is no statistically } \\
\text { significant difference in the mean } \\
\text { importance between the issues. }\end{array}$ \\
\hline
\end{tabular}

From the feedback, the mean values of the importance of each of the six HR issues were calculated along with their impact on time, cost and quality of projects. All these values are given in Table 2 . 
Table 2. Mean values of the importance and impact of challenging issues of human resources on time, cost and quality in IT projects

\begin{tabular}{|l|l|l|l|l|}
\hline \multirow{2}{*}{ HR issue } & \multicolumn{3}{|l|}{ Feedback of respondents } \\
\cline { 2 - 5 } & $\begin{array}{l}\text { Importance } \\
\text { of HR issue }\end{array}$ & $\begin{array}{l}\text { Impact on } \\
\text { quality }\end{array}$ & Impact on cost & $\begin{array}{l}\text { Impact on } \\
\text { time }\end{array}$ \\
\hline $\begin{array}{l}\text { New resources } \\
\text { operating new } \\
\text { technology }\end{array}$ & 6.06 & 6.61 & 6.33 & 6.42 \\
\hline $\begin{array}{l}\text { Availability of } \\
\text { resources }\end{array}$ & 7.27 & 6.91 & 7.18 & 6.79 \\
\hline $\begin{array}{l}\text { Skills of team } \\
\text { members }\end{array}$ & 5.45 & 6.61 & 6.64 & 6.45 \\
\hline $\begin{array}{l}\text { Retaining talented } \\
\text { people }\end{array}$ & 5.88 & 6.52 & 6.03 & 6.48 \\
\hline $\begin{array}{l}\text { Motivation, } \\
\text { communication and } \\
\text { coordination }\end{array}$ & 5.39 & 6.27 & & 6.52 \\
\hline $\begin{array}{l}\text { Employee-oriented } \\
\text { programs }\end{array}$ & 4.24 & 5.88 & 5.67 & 5.91 \\
\hline
\end{tabular}

Based on the results of means and impact values of all six HR issues, as given in Table 2, four graphs were developed and compared with each other, as shown in Figure 1.

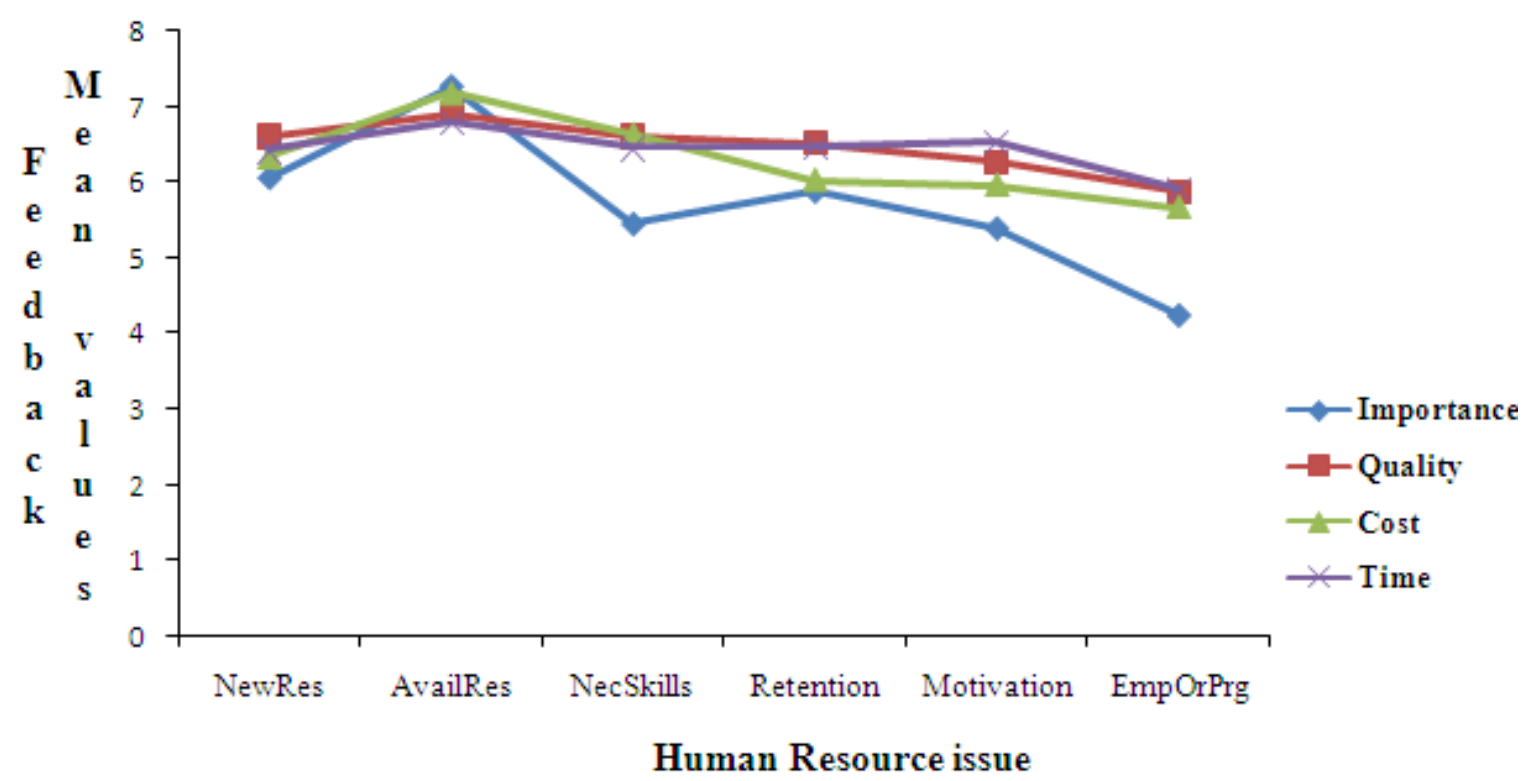

Figure 1. Importance and impact on quality, cost and time of six HR issues. 


\section{Results and discussion}

From the consolidated results, it was found that the HR issue of 'availability of resources' had the highest importance and the highest impact on time, cost and quality in IT projects. This was followe, in order of importance by the issue of 'new resources operating new technology', 'retaining talented people', 'skills of team members' and 'motivation, communication and coordination'. The issue of 'employee-oriented programs’ was rated least important.

In the case of impact on quality in IT projects, after 'availability of resources', 'new resources operating new technology' and 'skills of team members' had equal importance, followed by 'retaining talented people', 'motivation, communication and coordination' and 'employee-oriented programs'.

Regarding impact on cost of IT projects, the issue of 'availability of resources' was followed by 'skills of team members', 'new resources operating new technology', 'retaining talented people', 'motivation, communication and coordination' and 'employee-oriented programs’.

In the case of impact on time in IT projects, 'availability of resources' was followed by 'motivation, communication and coordination', 'retaining talented people', 'skills of team members', 'new resources operating new technology', and 'employee-oriented programs'.

Since for all three cases, that is, importance and impact on time, cost and quality in IT projects, 'availability of resources' was given the highest significance in the feedback from the questionnaires, it was attempted to confirm this further through personal interviews with other project staff with more than 10 years of experience in IT projects. The majority reported many IT projects had been lagging because of non-availability of the right human resources. Some project staff have been working on multiple projects in parallel hence their availability is not properly maintained for some of these projects. In addition, in IT field, the project staff often switch over from one organisation to another, in order to get more financial benefits, promotions and exposure to a variety of projects and environments. The project staff interviewed emphasised the significance of matching people skills with project requirements. They also attached the least importance to the issue of 'employee-oriented programs', pointing out that in the present competitive world, not only the market but also the IT staff are becoming more dynamic and are giving more importance to maintaining competence in the field. Hence IT organisations should recruit more skilled IT people and keep them on the projects. Proper loading and levelling of such resources should be done carefully, so that there is maximum availability of a particular resource for the relevant project.

\section{Conclusions}

The success of any project depends mainly on three important parameters - time, cost and quality. Because of the entry of new technologies, applications and market demands, IT projects are becoming highly dynamic in nature. Accordingly, the workforce in such IT projects faces several challenges to produce the necessary output with the necessary 
quality while saving cost and time. The six major human resources-related issues analysed in this study include 'new resources operating new technology', 'availability of resources', 'skills of team members', 'retaining talented people', 'motivation, communication and coordination', and 'employee-oriented programs'.

From the analysis of the data collected, all these six issues were assigned varying importance and priority in terms of their impact on improving quality and saving cost and time in projects. The issue of availability of resources was treated as the most important issue, whereas the issue of employee-oriented programs was rated least important. IT organisations should, therefore, give more importance in recruiting more skilled people and keeping them on projects and ensure their maximum availability to work on the assigned project.

\section{References}

Brooks, F.P. 1987, No silver bullet: essence and accidents of software engineering (Essay included in The Mythical Man-Month, Anniversary Edition, Addison-Wesley, 1995).

Brynjolfsson, E., Malone, T.W., Gurbaxami, V. \& Kambil A. 1994, Does information technology lead to smaller firms?, Management Science, vol. 40, no. 12, 1628- 1644.

Carneiro A. 2007, “What is required for growth?”, Business Strategy Series, 8(1), 51-57.

Duncan, W.R. 1996, A guide to the project management body of knowledge, Project Management Institute, USA.

Galunic, C.D. \& Rodan, S. 1998, Resource recombination in the firm: knowledge structures and the potential for Schumpeterian innovation, Strategic Management Journal, vol. 19, no.12, 1193-1201.

Jonscher, C. 1994, An economic study of the information technology, in Allen, T.J., Scott Morton, M.S. (eds), Information Technology and the Corporation of the 1990s, Oxford University Press, New York, NY, 5-42.

Lawler, J.J., Chen, S. \& Bae, J. 2000, Scale of operations, human resource systems and firm performance in East and Southeast Asia, Research and Practice in Human Resource Management, vol. 8, no. 1, 3-20.

Machin, S. \& Van Reenen, J. 1998, Technology and changes in skill structure: evidence from seven OECD countries, Quarterly Journal of Economics, vol. 113 no.4, 1215-1244.

Mirvis, P.H. 1993, Building the Competitive Workforce: Investing in Human Capital for Corporate Success, John Wiley \& Sons, New York, USA.

Pfeffer, J. 1994, Competitive Advantage through People: Unleashing the Power of the Work Force. Harvard Business School Press, Boston.

Rowden, R.W. 2002, High performance and human resource characteristics of successful small manufacturing and processing companies, Leadership \& Organizational Development Journal, vol. 23, no. 2, 79-83.

Schutz, W. 1994, The Human Element: Productivity, Self-esteem and the Bottom Line, JosseyBass Publishers, San Francisco, CA, USA.

Spitz-Oener, A. 2006, Technical change, job tasks, and rising educational demands: looking outside the wage structure, Journal of Labor Economics, vol. 24 no 2, 235-270.

Tsai, Hsien-Tang, Moskowitz, H. \& Lee, Lai-His. 2003, Human resource selection for software development projects using Taguchi’s parameter design, European Journal of Operational Research, vol. 151, no. 1, 167.

Rodriques, A.G. \& Williams, T.M. 1997, Software dynamics in software project management: towards the development of a formal integrated framework, European Journal of Information Systems, vol. 6, no. 1, 51-66.

Abdel-Hamid \& Tarek K. 1989, The dynamics of software projects staffing: a system dynamics based simulation approach, IEEE Transactions on Software Engineering, vol. 15, no. 2,109-119. 


\begin{abstract}
About the author
Nasina Jigeesh, $\mathrm{PhD}$ (Physics), $\mathrm{PhD}$ (Management Science - Project Management), is an Associate Professor and Head of the Department of Operations \& Systems at IBS Hyderabad, IFHE University, India. He has 25 years of experience in industry and academia, and has worked as a manager, project leader and project manager in several government and private IT projects from inception to implementation. He has taught project management, enterprise solutions for managers, data warehousing and mining, relational database management systems, e-business, business intelligence and analytics, and business modelling and simulation. He supervises $\mathrm{PhD}$ students in project management, knowledge management, supply chain management and customer relationship management. His research interests include business intelligence and analytics, data mining and system dynamics.
\end{abstract}

Email: jigeesh@ibsindia.org 